\title{
The rough guide to critics: musicians discuss the role of the music press
}

\author{
MATT BRENNAN \\ Department of Film and Media Studies, University of Stirling FK9 4LA, UK \\ E-mail:m.t.brennan@gmail.com
}

\begin{abstract}
This article explores the relationship between musicians and the music press from the musicians' point of view, based on a collection of recent interviews with musicians working in the pop and jazz fields. It will expose some of the concrete effects of the music press using examples from the everyday experiences of musicians, which include the influence of the press in record retail, genre labelling, and creating industry buzz. But while musicians may have a pragmatic understanding of the role of music criticism, their perspectives are emotionally heated in direct proportion to the influence the press holds over their own livelihoods. The interests of the working music critic often conflict with the interests of the working musician, and this article will conclude with a discussion of how the practical conflict of interests between musicians and critics is reflected in ideological differences between the two groups.
\end{abstract}

Richard Terfry writes, records and performs music under the name Buck 65. Although his fortunes have been increasing exponentially since he signed to Warner Records in 2002, for years Terfry struggled to make a living as an artist, working part-time at a news stand in his home of Halifax, Canada, to help finance the production and releases of his first five albums. Like many musicians trying to break through to a wider audience, Terfry is familiar with the practice of using the music press as a tool to gain exposure. His feeling that 'the music press is my best friend and my worst enemy' neatly sums up the paradoxical attitude held toward the press by most of the musicians I have interviewed over the course of my research. He goes on to relate an anecdote about his experience with $Q$, Britain's biggest selling music magazine, and why most music criticism has ceased to hold any personal meaning for him:

I've noticed that if you give someone - anyone, because this is just human nature - a record to listen to today they might hate it. Give it to them again in a week, they might love it. And that's the same for critics. Within the last year, I've seen the same record of mine get reviewed in $Q$ magazine twice, and the first review was really bad and the second review was really good. I don't know if they forgot that they reviewed it the first time, but what does that mean? What does that mean? Before I signed a deal in Europe, one of my first moves to make some sort of impact in Europe was to get a publicist, and I specifically wanted to get my record reviewed in $Q$, and then they wrote a bad review of it, and that was a bit of a kick in the ass. My publicist called them, just to follow up, and the guy he spoke to said, 'you know what, as it turns out, we received the record on the day of our deadline and didn't get a chance to listen to it'. But they ran a review anyway. And then months down the road they reviewed my record again, and I don't know if they had more time to listen to it, but they really liked it, and then lo and behold gave 
it a really glowing review. So in the end it doesn't really mean anything to me. (Richard Terfry 2003)

And yet, as Terfry becomes engaged in his story, the emotion in his voice betrays the fact that this does mean something to him - he can choose to actively disregard reviews of his own work, but he cannot escape from dealing with the press on a near-daily basis, nor the frustrations that can emerge from that relationship.

Musicians' attitudes towards the press are rooted in personal experience. Whereas previous research on music criticism has downplayed its economic influence, many musicians can offer accounts where reviews have had a seemingly make-or-break impact on an aspect of their careers. They therefore have a pragmatic understanding of the role of music criticism, but their perspectives are emotionally heated in direct proportion to the influence the press holds over their own livelihoods. It is often the case that the interests of the working music critic conflict with the interests of the working musician, and this article explores that tension. Having conducted a series of interviews with musicians working in the pop and jazz fields, I will examine some of the concrete effects of the music press using examples from the everyday experiences of musicians, and discuss how the practical conflict of interests between musicians and critics is reflected in ideological differences between the two groups.

\section{The role of the press in the music industry}

Researchers have traditionally found it either too difficult to calculate the concrete effects of music criticism on the livelihoods of musicians, or rationalised that music criticism somehow does not hold enough influence on consumer choice to make it worthy of investigation. Steve Jones writes that

it is difficult, perhaps, impossible, to assess directly the impact a critic has on sales of recordings and concert tickets. Shuker noted that 'there is general agreement that rock critics don't exercise as much influence on consumers as, say, literary, or drama critics' $(1994,93)$. One reason, as Shuker claimed, is that hearing music has greater impact than reading about it, and thus those who control airplay likely have greater influence on consumers. (Jones 2002, p. 4)

During a series of interviews with professional musicians and record label owners, however, I discovered that not only do many musicians perceive a direct impact on sales from positive press coverage or the lack thereof, but receiving the right kind of music criticism at the right time has become an integral step in the business of selling records and sustaining a musical career. This is especially noticeable for new or lower-profile musicians who lack the financial means to launch major advertising campaigns, produce high quality music videos or hire a full-time press officer to work for them. Nathan Wiley, for example, is a young Canadian singer-songwriter who released his debut album on a small independent label. As he put it:

Good press can make a really big difference, because it's one of the only ways to make people sit up and pay attention to what you're doing, without having anyone really behind you. To put a record out there with no money to promote it and make videos and get it on the radio, to get good reviews from a major paper or something, will bring your record to the attention of people. (Wiley 2003)

Wiley's album did in fact earn rave reviews from major Canadian newspapers and magazines, and soon after he gained a distribution and promotional deal with Warner Records. His success story is a typical one. However, what has stumped 
analysts in the past is demonstrating a concrete cause-and-effect link between positive press coverage and major label interest or impact on record sales. But these links have become increasingly firm in the past few years, and what follow are a few first-hand accounts from label owners about the ways in which music criticism currently holds a crucial influence over the commercial viability of musicians' work. My account of the role of critics in the music industry will centre on the cases of two Scottish record labels: Chemikal Underground and Caber Music.

Chemikal Underground 'started life in 1995 as a vehicle for the music of the band The Delgados ... [It] enjoyed early commercial success with the band bis and from there went on to sign a number of critically acclaimed and commercially successful acts such as Mogwai and Arab Strap', and according to a recent report on the Scottish music industry, Chemikal Underground is widely recognised as 'Scotland's leading independent rock label' (Williamson et al. 2003, p. 105). Caber Music was formed slightly later in 1998, but quickly earned a reputation as an innovative leader amongst UK jazz labels and produced a steady stream of critically lauded albums, including releases by Brian Kellock and Colin Steele. Both labels were headed by musicians who, in addition to managing successful artist rosters, recorded and released their own material. Stewart Henderson was the bass player for the The Delgados, the former Glasgow-based band who collectively owned Chemikal Underground and made up its board of directors. Tom Bancroft is a jazz drummer and composer who performed with numerous ensembles and owned and operated Caber Music. Both Henderson and Bancroft revealed that favourable record reviews, concert coverage, and feature articles are essential to the livelihoods of musicians, who lack the cash flow for substantial promotional campaigns typical of bigger labels. According to them, the key to understanding the influence of critics is the connection between music criticism and the music retail landscape. [Caber Records ceased operations in 2005; the Delgados broke up the same year but still operate Chemikal Underground.]

\section{The role of critics in ... record retail?}

The majority of records in Britain are sold in supermarkets such as Asda, Tesco and Safeway, and in department stores such as Woolworth's. ${ }^{1}$ But these stores stock an extremely limited selection of albums and rarely, if ever, provide shelf space for indie and specialist genre albums. Instead, albums that do not reach the UK music charts must rely on a small number of major CD retail chains and independent record stores for their sales. Tom Bancroft explained that as few as five major chains (HMV, MVC, Virgin, Borders and Tower, which has now ceased trading in Britain), make up roughly 75 per cent of jazz sales, and that the structure of music retail has been changing in recent years: all of the major chains now stock CDs using 'central buyers', meaning that five people are responsible for deciding what gets sold in 75 per cent of the market. (In some cases, this change has occurred as recently as three years ago, when Caber Music was still able have its music stocked in the Edinburgh Virgin store, which had an individual buyer.) The remaining sales occur mostly through independent music stores (15 per cent), of which only twenty sell significant amounts of jazz, and Amazon ( 5 per cent). This means that only twenty-five people in the UK decide whether a jazz album will be sold to a mass audience.

In addition to central buying, the five major chain stores have become increasingly powerful by introducing the practice of 'retail packs'. Stewart Henderson noted that 'there are so many new releases out there now that the shops can ill afford to fill 
their shelves with slow moving stock'. To solve this problem, buyers only take in a limited number of new releases from a given genre every month:

At HMV there's 24 non-pop retail packs up for grabs every month. And that's for folk, world music, classical, and jazz. If you don't get one of them, you're not going to sell even 1000 records. (Bancroft 2003)

This not only makes retail packs highly competitive (there are a larger number of available 'pop' retail packs, but the same principles apply), but can mean almost guaranteed commercial failure for independent artists not offered a pack. An HMV retail pack, for example, includes stocking at least five copies of the album in every store in the UK, getting racked on a 'new release' or equivalent high profile shelf, and a small write-up or ad in the HMV Choice in-store flyer. In exchange for these privileges (one of which, remember, includes the album being stocked at all), labels are expected to pay the chain a retail pack fee.

The other catch is that an artist cannot request a retail pack: they must be offered one by the central buyer. Stewart Henderson explained that before an album is released, buyers "will demand to see a "plot" for each release in order to justify freeing up the shelf space/offering retail packs'. According to him, this plot consists of:

1. High Profile in the Press (good reviews across the board/ideally features in key publications)

2. Radio Airplay (the more the better)

3. Band Activity (tours/promo/radio sessions/interviews)

4. Band Retail History (this will be taken into account to a lesser extent)

For new and non-radio friendly independent artists, criteria (2) and (4) are irrelevant, meaning that good press and a high band profile at the time of release are essential for an album to even have a chance of reaching a mass market. A Scottish band, for instance, will have to arrange to launch a new CD release with a concert tour that places them in London roughly three weeks before their album hits store shelves in order to get crucial coverage from national music publications:

Retail chains have become increasingly powerful in that they are much more choosy about what hits their high profile shelves. [With the necessity of presenting a press plot], pressure is placed on the label to time all promotion so it coalesces into a convincing whole at the time of hitting retail. (Stewart Henderson 2003)

[Buyers are] looking for a picture of critical press coverage that's going to drive sales, and if they don't see that predicted, then they won't stock the album. You have to get the reviews at the right time as well, which is why it's frustrating, 'cause you could get a really good review a month late, and it's not going to change sales by much at all, because it's not going to be in the shops. (Tom Bancroft 2003)

Accepted marketing practices therefore include currying favour with journalists to provide guaranteed positive reviews before an album's release. What is most clear, however, is that music criticism plays a direct role in getting records onto store shelves.

\section{The role of the press in genre labelling}

Not only do favourable reviews have to be timed to coincide with the release date of an album, but the coverage must come from the right kinds of publications according 
to the genre conventions of the music industry. An indie rock release will need praise from Kerrang! but not The Herald, whereas a jazz album will need the opposite. This process of genre categorisation can create frustration among artists who see their music as actively transgressing genre boundaries: they must either play the game of pigeon-holing their music to market it effectively, or face the prospect of being ignored by both central buyers and major labels. Those who wish to see their albums reach a mass audience, however, recognise the importance of the link between genre labels and successful album marketing:

From our point of view [as an independent rock label], if you were to look at the magazines around at the moment that are important, you would say $Q$, Uncut, Mojo, NME, and in the rock area things like Kerrang! and Rock Sound. And then beyond that you have the style magazines like Face and ID and all these things, and then below that again, not necessarily below that, but you've got all the broadsheets and tabloids. So, I mean, all those magazines I mentioned are only half a dozen, so if you don't get written about in one or two of those magazines, that's a disaster, it's a disaster! (Stewart Henderson 2003)

This press hierarchy for the independent rock field finds glossy music magazines at the top and broadsheets roughly at the bottom of the list. But this hierarchy is reversed in the jazz sector: quality dailies become the most desirable form of coverage, while jazz magazines are relegated to the bottom:

This is what they [central buyers] want: Independent, Times, Observer, Guardian. All within the space of three weeks. The most important thing is Guardian CD of the week. If you say to them, 'we're going to get CD of the week in the Guardian', then you'll get a retail pack offer. But you want to have all of those main quality dailies and Sunday papers, and that should be enough to get you in. Anything else, radio play, specialist magazines, is a bonus. Broadsheets are where it's at for jazz. You could get a fantastic review in Jazz Review, Jazz Wise, Jazz UK [specialist jazz magazines], doesn't really make a huge amount of difference to the distributors. The readership's very low - it's for fans and nerds, and they can buy in lots of different ways [through the website, special order], whereas getting five copies into every HMV in the country, getting it racked, getting space in HMV Choice, that's when you start to sell some volume, and for that they want to see broadsheet reviews tied in with the release date. (Tom Bancroft 2003)

It is important to remember that both Bancroft and Henderson operated independent labels with mostly new or relatively low profile artists. Established artists with proven sales records operate differently. Tommy Smith, for instance, has been a saxophonist and composer for over twenty years, he has released albums with both major and independent record labels (he currently runs his own label, Spartacus Records), and is arguably the highest profile jazz musician currently living in Scotland. Smith provides a counter-example of an established musician who made his name in a time before retail packs and press plots:

My best selling records have had the worst reviews. My worst selling albums have had the best reviews.

MB: Tom Bancroft said that his distributors have found that to get offered a retail pack in stores, getting Guardian 'CD of the week' really helps. In your experience, is that true?

I wouldn't know. We get CD of the week every year for every record we release. It's not anything new, it's predictable. You get it if you make a good record. Same with the Observer. It's just hard to gauge. Depends on how much research you do. I've been around a lot longer than some of the artists on Tom's label, so it's easier for me. I don't need to sell myself.

$M B$ : Your name is a sign of quality?

I suppose - but if you put out a bad record then you're gonna lose it. If I put out a pop record, that's the end of the road! (Smith 2003)

Smith and established artists like him operate differently, as do artists with majorlabel funding; they will be guaranteed to be stocked regardless of critical acclaim 
because they either have a history of retail success or can afford to run a larger advertising campaign. But for most artists who have not been afforded such a lucky break, good reviews from the right publications are of the utmost importance. But even Smith, like Henderson and Bancroft, admitted to being mindful of genre rules. He earned his reputation playing jazz, and an attempt to cross over to 'pop', in his mind, could spell artistic and commercial ruin.

Some musicians find it very difficult to connect their music with a marketable genre. Richard Terfry, quoted at the outset of this paper, used to be firmly rooted in an old school hip-hop tradition, and his first four albums made extensive use of breakbeats, samples, turntable scratching and rap-influenced vocals. ${ }^{2}$ With his more recent records, however, he said that for as much as hip hop has been an influence, 'so was King Tubby, so was Brian Wilson, so was Bob Dylan, Tom Waits, all sorts of things and no one more so than the other. So what do you do? There's not a name for it' (Terfry 2003). The importance of genre labels in criticism has therefore become highly problematic for him:

The main problem I face these days is that, in the simplest sense, most people see me fitting into the hip-hop category. So there I am, lumped in with all the other hip-hop stuff. But I can tell you, your average person who isn't a fan of hip-hop thinks of one thing when they hear the word. Even when someone writes 'this is a great hip-hop record, it's none of that usual crap you've come to expect', but sometimes that's about all they say. And so for someone who's a Johnny Cash fan, it means he reads that review and it's probably not saying much to him. 'Well, it's still a hip-hop record, and I'm just not interested'. Sometimes just that word being there, especially if it's not followed up, is just enough. In my mind, these days it's just a dirty word, a bad word . . . because I've had people say, 'normally I'm a big fan of Tom Waits, Bob Dylan, and I like your record, who would've thought?' And so it's like 'how can I get my stuff into their hands', how can I make the press work for me in that way? I don't even really know. (Terfry 2003)

Stephen Fearing is another musician frustrated by the genre branding process. Fearing is a Canadian acoustic guitarist, singer and songwriter, and is often labelled as a folk musician by the press:

MB: Define folk music.

I can't, and I hate the term. Actually, I don't hate it, but I'm frustrated with it, because it depends on the culture you come from, to define what it is. Labels and classifications pretty often just come from the industry side where they literally have to find a box in the store to put you in. (Fearing 2001)

Fearing's assumption is correct according to Simon Frith, who explains that the matching of an artist to a particular genre is a well-established practice of the music industry:

Genre distinctions are central to how record company A\&R departments work. The first thing asked about any demo tape or potential signing is what sort of music is it, and the importance of this question is that it integrates an inquiry about the music (what does it sound like) with an inquiry about the market (who will buy it). The underlying record company problem, in other words, how to turn music into a commodity, is solved in generic terms ... decisions about recording sessions, promotional photos, record jackets, press interviews, video styles, and so on, will all be taken with genre rules in mind. (Frith 1996, pp. 75-6)

As much as he felt the labelling process is entrenched in the music industry, however, Terfry suspected that there was a way to eventually break free from the labelling game:

You start dealing with the major press, people at record companies, and booking agents, and video channels, and all these other things, people, places that need categories. Things have to be 
a certain way in order for it to make sense for them. So I face that. There is this never-ending need that critics and editors at magazines have to fit things into a category. Unless you get the rare case, someone like Beck, someone like Bjork, who have managed due to perseverance to just transcend it all - 'well, she's just Bjork', 'he's just Beck'. You just have to say their names and you've got it. You don't need to compare them to anyone else, and if anything, they've become one of the names that other people get compared to sometimes. (Terfry 2003)

Where do the Becks and the Björks of the world fit in? These exceptions are worth a case study on their own, but the important point in the context of the press is that they are exceptions to the rule; for Henderson and Bancroft, who learned to deal effectively with the press, there are compelling financial reasons to adhere to genre rules - to clearly establish a certain kind of music for a certain kind of audience.

\section{The role of the press in creating industry buzz}

The unpredictability of the popular music market is evidence enough that consumers seldom treat the opinions of the music press as gospel truth. A guaranteed loyal readership, however, will be the record executives and retailers who have a commercial incentive to keep up with the latest musical happenings and trends. Critics' year-end round-up lists are a perfect example of how critics hold more influence over the industry than the punter:

The BBC Jazz awards and critics' year-end lists don't boost sales hardly at all, because they're not tied into retail. You look at the Brit awards for pop and rock, then you'll have racking in all stores of all the nominees and lots of features in HMV Choice. HMV sponsor the Brit awards, so they're completely locked in with retail. Whereas the BBC Jazz Awards has only been going for two years, and it has no relationship with retail whatsoever, so sales don't respond to it. What is significant about those awards and lists is that they tend to reflect the status of the label in the industry, and the status of an artist as well. So the fact that we've [Caber Music] had an album of the year in the Guardian list for the last two years - and we're the only British label to do that - is fantastic for us, because people think we're really high quality and we're really good. And so people can't ignore us, they can't say 'well, who are they?' Those things keep us in the industry's mind. (Bancroft 2003)

In other words, ending up on a few 'best of year' lists may not generate a response in consumers per se, but could catalyse a chain reaction of media buzz that fuels a perception of the artist or label as 'hot', igniting the attention of the industry. One of Caber Music's more successful artists was Brian Kellock, a jazz pianist who spent most of his career in relative obscurity until he won the BBC Jazz Award for 'best UK pianist' in 2002. He believed that the award started a chain reaction of coverage across the board:

MB: You've been getting reviewed by London publications like the Observer and the New Statesman. Well, I've only just started getting reviews basically since the album got the [BBC Jazz] award and things. (Kellock 2003)

That's the thing about press, it has two audiences, the industry audience and the punter. And the impact on punters is less significant. It will only have an impact on punter if they walk into a record shop and they see the CD - 'oh, I read about that one!' - whereas the industry is really the more important reader in the long term. We had this feature on us by Miles Kington in the Independent. It's very difficult to get a jazz coverage in the UK dailies, and it's very competitive, and columnists like Miles, who are just writing general feature articles, almost never mention jazz. So he wrote this completely unprompted piece, we had no PR going on or anything. It was a fantastic, positive piece about the label, and the buyer called me and said, 'do you know what happened today? Have you seen the Independent?' I had the buyer from fucking HMV phoning 
me - which has never happened before, the buyer never phones the distributor, you're always chasing them - going 'have you seen the Independent, there's this incredible piece', so that kind of thing is worth a lot. It means that the buyers are going 'these guys are getting noticed'. It keeps you in the frame. (Bancroft 2003)

Another example came from Henderson, whose band the Delgados were nominated for a Mercury Music Prize with their album The Great Eastern. The Mercury Prize is similar to the Brit Awards in that it is strongly linked to retail, and thus a nomination can seriously affect album sales. ${ }^{3}$ Unfortunately, the Delgados were not able to reap the full rewards of this nomination due to another hard lesson learned about the role of the press in the industry. If a ubiquitous, high-profile artist like U2 is nominated for a Mercury prize, then their already giant sales will hardly be affected. But for many low-profile artists, a Mercury nomination can yield instant public attention, sometimes resulting in a dramatic boost in albums sold. Yet the pay-off can be deceptively low if such an artist lacks major label funding:

Chemikal Underground is not a cash organisation, so cash flow is quite tricky for us. We were really reaching the outer limits of what we could afford to spend on The Great Eastern, and then when the Mercury nomination came along, we were initially flushed with an unbelievable excitement about what it would mean for us, and all the albums we would sell, and the money that that would bring in. Unfortunately, retail chains like HMV told us that we would have to pay for a package to get our CDs up on the special Mercury nominations racks in stores.... additionally they told us 'we're gonna take an obligatory $25 \%$ cut on every copy of the album, and a retrospective $25 \%$ on all of your CDs in our warehouse that we took previously'. They've got you by the throat! You have a window of opportunity when you get nominated to exploit the album as much as you can, and if we'd had more money, we would have perhaps been able to re-advertise the album in magazines, take journalists to our gigs to do features, but we just never had the money to do that. ... as a result, of all the albums that were nominated that year, The Great Eastern ended up being one of the least visible ones of the shortlist, and I think that's obvious when you see the sale-through we had on it. (Henderson 2003)

Funding from the deep pockets of a multinational record company cannot ensure an artist's commercial success, but it certainly helps. Critical acclaim can potentially serve as a platform for low-profile and independent musicians to boost their audience, but even if they are savvy enough to be able to run a successful press campaign, money and resources would be stretched further than most self-funded artists can handle to properly exploit their good press with tours, advertising and TV appearances. The kind of capital needed to take their profile up that extra notch and keep the chain reaction going is rarely available without the support of a major label and its press officers. Once again, however, without favourable press coverage, the work of artists who have minimal financial backing to sustain their careers would be even harder.

\section{The ideology of musicians regarding critics}

Let us return for a moment to Richard Terfry's anecdote about $Q$ magazine, quoted at the beginning of this article. His comments betrayed two common suspicions musicians have about music criticism: that it tends to be (1) self-important and (2) uninformed. The critic in Terfry's story decided that the editor's deadline was more important than properly reviewing the album; he handed in a review with no apparent regard for the potentially negative consequences it would have for the artist, unwittingly providing another example in a long list of musicians' stories about how critics are out to serve themselves, not the music. The first review of Terfry's 
album was also clearly uninformed, but to cast even further doubt on $Q^{\prime}$ s credibility, it was possible that the same album could be given contradictory star ratings in the magazine, effectively rendering any pretensions of objectivity or agreed critical standards meaningless. I will tackle these assumptions about the music press one at a time, beginning with the argument that the press is self-important.

Gordon McIntyre is the lead singer and songwriter for the Edinburgh-based band Ballboy. He had this to say about music critics:

I think that there's an attitude amongst music journalists that they are more important than the people making the music. And they're not. Even if the person who's making the music is rubbish, even if they're making rubbish music that nobody would like, it's still better than to be writing about the person making the rubbish music. (McIntyre 2003)

Barry Burns, multi-instrumentalist for the Glasgow-based band Mogwai, agreed:

Music does not 'need' the press but the press needs music. The press seem to forget that point and hijack the whole affair, telling us what we should and shouldn't like. (Burns 2003)

As we have seen, music critics exert a surprising amount of influence on the livelihoods of musicians, especially lower-profile musicians who are attempting to make a bid for national exposure and distribution. It may be true, as Burns puts it, that music 'does not need the press', but musicians need press coverage to reach new audiences. John MacLean, a DJ, programmer, and part of the former Edinburghbased Beta Band, suggested to me in an e-mail interview that he would get rid of critics altogether and rely on first-hand experience and word of mouth (MacLean 2003). Yet even if the current music press industry was suddenly vaporised, those who listened to the music first hand would still talk about their experiences afterwards - word of mouth, as Maclean put it - and it is a slippery slope from word of mouth to e-mails, letters, fanzines, and so on. A market exists for professional music journalism, and the conflict between musicians and critics is rooted in competing interests between artists trying to earn a living through releasing records and performing, and critics earning a living by writing about it. Neither job is generally well paid, and the two groups will obviously have conflicting systems of ideas and values that support their own professional interests: in short, musicians and critics will have clashing ideologies. So while musicians can often offer practical insights about how the music press works based on their personal experiences, these views are always couched in an ideology that prioritises the values of musicians over those of critics.

The press is a self-important entity, but so is any commercial business, including record labels and musicians' unions. Any good business will seek to survive and grow, but according to the ideology of musicians, the press ought to have nobler intentions than simply making money. Its primary goal ought to be to foster a forum for the music scene. Take, for example, John MacLean's concern that 'too many critics get caught up in trying to find something new or cool', a complaint echoed by many other musicians. 'We don't concern ourselves with fashion or hype', he said of the Beta Band, 'we want to make music that doesn't date' (MacLean 2003). The music press, especially publications with hype-oriented editorial policies, like the $N M E$, are constantly hungry for 'what's new, but not necessarily what's good'. Richard Terfry expressed similar sentiments:

At any given time, Johnny Cash may be cool or uncool, but is that going to suggest that sometimes he sucks, sometimes he doesn't? But that's the impression you would get, because 
the press worries too much about coolness instead of what's good, and I don't think that should be their role. In fact, I don't know whose role it should be to say 'alright, I'm going to be the one who's gonna say what's cool'. And to me, that's my number one, bottom-line complaint with the press: they have assumed the role for themselves as the pundits of cool. They have that power. (Terfry 2003)

Stewart Henderson believed that pandering to 'what's cool' versus 'what's good' was a deliberate ploy on the part of magazines to maintain a hold on or increase their readership. He felt $N M E$ in particular is guilty of 'playing to an audience that they know they can keep and work', inevitably at the expense of giving positive press coverage to artists and bands who are deemed as 'uncool' or 'yesterday's news'. The $N M E$ in particular appeared to have a policy of printing sarcastic, derisive coverage of bands deemed 'uncool' (Henderson 2003). ${ }^{4}$

The musicians quoted above were concerned that the press uses music coverage as just another tool to secure readerships, rather than as an unfettered forum for debate about what music is worth hearing and why. 'Garage rock' may be the flavour of the month, and championed by the press, not because it is objectively any better than other genres, but simply because it is fashionable. Forde (2001) and Frith (2002) have substantiated these claims to an extent in their work on the current climate of genre-branding in the music press. Frith writes that when he worked as a critic for the Sunday Times:

I soon realised that a good press office was one that did not waste my time, that understood my tastes and readership and pitched me records and concert tickets accordingly ... Such matching of taste and publication soon resonated with the ways in which magazines and arts editors were themselves seeking an edge in an increasingly competitive market. Branding in this context meant associating a publication with a genre. (Frith 2002, p. 242)

The second common complaint from the musicians I interviewed was that music criticism is often uninformed. Sometimes this is a matter of a critic simply lifting quotes from a press release and pasting them into a supposedly 'original' article. Stewart Henderson had the job of both sending out press releases to music magazines and collecting the clippings of any press coverage that follows. 'There is nothing worse', he said, 'than reading a review which you know for a fact is just regurgitating the facts in the press release. It's just lazy, and it's not so much ill-informed, because it is informed by the press release, but it's not informed by any thought that the critic's put into it ... you see that a worryingly high amount sometimes' (Henderson 2003). However, musicians are also sometimes rankled by coverage that lacks any critical discussion of the music itself. Brian Kellock remembered a particular review about one of his jazz piano concerts:

There's one guy in the Evening Standard who just kept harping on about how I looked like Phil Mitchell out of EastEnders [a popular British soap opera], which was nice, very musically astute of him [laughs]. Sometimes that stuff takes up $60 \%$ of the review, maybe because the guy doesn't know what he's talking about. (Kellock 2003)

Kellock argued that descriptions of a performer's biographical details and fashion sense were not what he considered to be elements of an informed critical discourse; in fact, a critic who devotes too much article space to the former elements might be suspected of musical ignorance. Kellock's argument implies that there is a difference between the critical discourses of musicians and critics, and this may be additional evidence of conflicting ideologies. Saxophonist Tommy Smith shared his view about the difference between journalistic writing and his own way of talking about music: 
I have a publicist, and she writes the press releases in language that excites press people. The language I would use would bore them to hell.

$M B$ : What language is that?

The truth! Musical truth, more down the line of explaining what it's all about if I have a new record. I used to write them myself, and I had people say to me, 'maybe you should get someone else to write them for you. They're too anal'. (Smith 2003)

Smith was distinguishing between two approaches to writing about music: technical vocabulary versus metaphoric, emotionally exciting language. When he described the former as more 'truthful', it is because that musical discourse is agreed upon by a community of jazz saxophonists, and therefore such judgements are objective within that community. A pentatonic scale will always be described as such in jazz, and Smith can criticise a student for not having learned one properly. For Smith, then, music criticism is possibly 'dishonest' to the extent that it relies on the second kind of language - the colourful, metaphorical kind - where a journalist might describe a pentatonic scale as 'an exhilarating (or tedious) flurry of sound'. But without a clear set of aesthetic principles shared by both musician and critic, sometimes artists are left surprised and irritated by what earns critical acclaim.

If you're a person who, to think of the crudest example, farts on record, you're probably going to find a following out there. And that's something that you can really struggle with as an artist; [especially] if you've seen something that you think is total garbage do really well in the press and sell lots of copies. What does that mean? That kind of just pulls the carpet right out from under you, it makes the framework really irrelevant. (Terfry 2002)

Some musicians subscribe to an argument most famously expressed by Elvis Costello, who once said that 'writing about music is like dancing about architecture. It's a really stupid thing to want to do'. For them, music is an ineffable art form, and therefore any writing about music is inevitably going to fail to capture what is essentially inexpressible:

I get so many e-mails asking what a particular song meant, and I can't answer. I'm not $100 \%$ sure what it means, the reason I wrote it was I was trying to explain something that I couldn't just say or speak out loud. And then the critic narrows it down - the thing that possibly infuriates me the most is someone saying 'what he's trying to do is', or 'what he's saying is', - so the song you made ends up getting compressed into this tiny little nugget of coal. (McIntyre 2003)

Some interviewers have been appalled when they meet us, because they talk about emotions and influences and beautiful soundscapes in our music. But we just liked a tune enough to try and make it sound as good as we can. There is no literal meaning behind a Mogwai tune! Some guy even called our songs cynical - how can they be cynical without words? ${ }^{5}$ (Burns 2003)

But the 'dancing about architecture' point of view is an ideological one. Most musicians see no problem in talking about music using their own forms of discourse, and would no doubt find managing rehearsals efficiently to be a near impossibility without the use of speech. The 'dancing about architecture' argument is really implying that the only people who are truly qualified to talk about and hence judge music are the musicians themselves, just as Tommy Smith implied when he described the discourse of musicians as 'the musical truth'.

Practical experience and ideology coexist in musicians' accounts of the music press, and the tension in their arguments increases in proportion to the influence the press holds over their livelihoods. Tommy Smith, who had been the longest practising professional musician of those I interviewed, summed up the problem: 
I really don't care. I mean, after you've been criticised for 25 years, you really don't give a shit anymore.

$M B$ : What about at the beginning of those years?

When you're young? Of course, you need, you want good reviews. Everybody does. (Smith 2003)

Favourable press coverage is not simply a matter of musicians getting their egos stroked; without it, they jeopardise their livelihoods. Stewart Henderson, like many, feared that critics may simply not be aware that what they write may have serious consequences for artists:

Critics could certainly make the argument that 'it's just my opinion, take it or leave it'. The frustration if you're in a band is like, yeah it would be very nice if it was just as straightforward as that; but you know for a large amount of people, it isn't just your opinion, it's the entire circulation of your magazine's opinion once they read it, unless they are strong willed enough (or they're already a fan of that band and will disregard the bad review and buy it anyway), or go and seek out a good review and formulate a balanced opinion on that record. If we don't sell enough records, then we get dropped by our publishing company, which is our only wage, and we have mortgages to pay, and the bands splits up. It's as simple as that, it's not a melodramatic statement. Now obviously the argument is, good songwriters will rise to the top, and if you make good records you'll do alright. But I could paper the walls of my house with albums that were fantastic that never sold any. (Henderson 2003)

Henderson argued that there is nothing wrong with being critical of an artist's music - indeed, musicians are highly critical themselves - but the act of criticism is complicated when the individual opinions of critics acquire significance in the music industry. When critics voice their opinion to a mass audience, what is usually a matter of individual taste becomes a matter of morality. They have the power to shape and inform the opinions of both the industry and consumers, and it is here that the ideologies of critics and musicians truly clash. Critics might argue, for instance, that some music is universally bad, and it is therefore their responsibility to steer consumers away from it. Musicians generally make a different assumption: I once pressed George Porter Jr (a studio bass player and member of the New Orleans band, The Meters) on whether he felt there was such a thing as universally bad music. To which he responded:

Just 'cause I don't like it, that don't mean that I have a call on what's good and bad music. MB: But following that, does that mean there's no such thing as bad music?

Absolutely! I don't think there's no bad music out there. I think that every note played is good to somebody. Even if it's played in the wrong key [laughs]. (Porter Jr 2001)

Does it follow that musicians think there should be no negative coverage or bad reviews whatsoever? Some seem to take this view, such as Nathan Wiley, who felt that if a critic gets asked to review a record they do not like, the critic ought to 'pass on it rather than give someone a bad review. Just because they don't get what that artist is trying to do, doesn't mean that it's not a good product' (Wiley 2003). On the other hand, Tom Bancroft felt that policing criticism is 'a very dangerous road to go down', because without a range a of critical opinions, 'you get the situation where people don't say what they think, and then you can't really judge the good ones from the bad ones. A good review doesn't mean so much' (Bancroft 2003). And negative criticism done well, according to Bancroft, can sometimes be a positive experience for an artist:

We got a bad review for one of our releases last month, and I think it was fair. I think it was good for the artist as well ... Good critics can provide important feedback to the artists on what 
they're doing, so for the development of the music it's important to have people out there. (Bancroft 2003)

Even John MacLean, who earlier proposed the solution of 'getting rid' of all critics, admitted later that criticism done well can provide valuable feedback for musicians: 'Sometimes critics may highlight a problem that we don't realise because we're too close to the material' (MacLean 2003). However, it would be going too far for any musician that I spoke with to attempt to make music specifically to please critics. Gordon McIntyre cautioned that, 'you should cut your hands off before you even consider it', confirming that the tension between musicians and critics is unlikely to be resolved anytime soon.

\section{Conclusion}

Several attempts have already been made to explore issues of practicality and ideology in the music press; but these accounts have almost invariably been from the perspective of the writer, who may have worked as a professional journalist or scholar, but rarely as a professional musician. ${ }^{6}$ Consequently, discussion of the relationship between musicians and the press has been a predictably one-sided affair. We can only understand the world of music criticism by recognising the points of view of all the stakeholders, which includes both critics and musicians. The press clearly matters to the latter group, and the ways in which it matters are not as intangible as writers have suggested in the past. It is difficult to generalise about the relationship between musicians and the press, because the press performs different functions according to the career status of the musician in question; but there is evidence that critics are increasingly playing the role of gatekeepers for lower-profile musicians, as they attempt to make the career jump to national distribution and exposure.

There is also an ideology of musicians that reflects the contradictory nature of their relationship with the press. Musicians can be cynical in their discourse about the music press process, and yet they need that process to work for them in order to maintain and expand their audience; in fact, it is their dependency on the press that often gives rise to an animosity towards critics. More than this, however, they are dependent on a group with different priorities than themselves. Whereas musicians tend to focus on the 'music itself', critics, both at the institutional and discursive level, bring artists and their music into broader social and commercial contexts. In this case, the 'dancing-about-architecture' line may be a defensive ideological strategy on the part of musicians that reflects their relatively weak position in shaping music discourse, and in the case of lower-profile musicians, belies their frustration with the influence of the press on their livelihoods.

There are many parallel problems that emerge in the ideology of critics themselves, and although it is not within the scope of this article to fully compare the two groups, what musicians and critics share is the problem of dealing with the tension between aesthetics and business, between art and commerce. This problem is manifest in their everyday career choices as they work and interact with one another. There is still much work to be done in this area, such as addressing the question of whether this tension applies across all fields of the music press, or examining how the tension between art and commerce in the press has developed over history. It will be interesting to see what answers can be found for the questions raised in this article as historical and analytical research on the music press continues. 


\section{Endnotes}

1. For precise retail market statistics, see the British Phonographic Industry website, www. bpi.co.uk

2. Although the definition of the label 'old school' shifts according to who you talk to, I use it here to refer to hip hop music where the instrumental tracks rely on samples and drum breaks lifted from vinyl records, and feature the use of turntable scratching. This differs from most contemporary hip hop on the music charts, which mainly uses keyboard synths, drum programming, and contains little or no scratching.

3. For more on the commercial consequences of Mercury Prize nominations, see 'Mercury list boosts award outsiders' (BBC News 2003).

4. Henderson goes on to recount an anecdote about the difference in $N M E$ coverage of his own band, The Delgados, versus label-mates Mogwai, who were heavily championed by the magazine. 'We were told editorially that we were simply not an NME band and would not be covered by NME. So that was an example of how NME operate, and how they will select bands and say, 'you're in', or 'you're out' kind of thing. And we were out, to the frustration of certain journalists who were staff writers at $N M E$, but from an editorial point of view, that was what we were told. Now that was broken down slightly with The Great Eastern [the Delgados' Mercury-nominated album] . . . the NME couldn't be seen to ignore us when people were talking about us to such a degree ... We were eventually given a feature by NME in the most grudging manner possible. The thrust of that interview we did for that feature was deeply insulting for us. Basically a guy came over and said to us, lots of people at the NME think you're shit. Tell us why you're not. That was our feature'.

5. It should be noted that Mogwai's song catalogue is almost entirely instrumental music.

6. Lindberg et al. (2000) provide an excellent historical account of the ideological shifts in the press as they consider 'the specific contribution made by rock criticism to the construction of rock as 'serious' music' (p. xi). Gorman (2001) has conducted interviews with a large number of music journalists and compiled the most interesting excerpts into a book, and upon reading it becomes clear that like musicians, critics' reflections on the press are mixed with practical insight and ideological arguments. Finally, Jones (2002) has recently edited the first collection of essays devoted to scholarly analysis of the popular music press, covering a wide range of issues and genres.

\section{References}

Bancroft, T. 2003. Interview with the author in Musselburgh, 26 May

BBC News. 2003. 'Mercury list boosts award outsiders', BBC News Online, 25 July, http: / /news.bbc.co.uk/

1/hi/entertainment/music/3097483.stm (last visited 26 April 2004)

Burns, B. 2003. E-mail Interview and correspondence, March

Evans. B. 1957. 'New York', Down Beat, 23 January

Fearing, S. 2001. Telephone interview, 16 July

Frith, S. 2002. 'Fragments of a sociology of rock criticism', in Pop Music and the Press, ed. S. Jones (Temple), pp. $235-46$

Frith, S. 1996. Performing Rites: On the Value of Popular Music (Harvard)

Forde, E. 2001. 'From polyglotism to branding: on the decline of personality journalism in the British music press', Journalism Studies, 2/1, pp. 23-43

Gorman, P. 2001. In Their Own Write: Adventures in the Music Press (Sanctuary)

Henderson, S. 2003. Interview with the author in Glasgow and e-mail correspondence, April-June

Jones, S. (ed.) 2002. Pop Music and the Press (Temple)

Kellock, B. 2003. Interview with the author in Edinburgh, 9 May

Lindberg, U., Guomundsson, G., Michelsen, M., and Weisethaunet, H. 2000. Amusers, Bruisers and CoolHeaded Cruisers: The Fields of Anglo-Saxon and Nordic Rock Criticism (Arhus)

MacLean, J. 2003. E-mail interview and correspondence, March

McIntyre, G. 2003. Interview with the author in Edinburgh, 9 May

Porter, G . 2001. Interview with the author in Great Barrington, USA, 11 August

Smith, T. 2003. Interview with the author in Edinburgh, 21 June

Terfry, R. 2003. Interview with the author in Glasgow and e-mail correspondence, April-June

2002. Interview with Susana Ferreira in Sackville, Canada, 31 January

Wiley, N. 2003. Interview with the author in Fredericton, Canada, 21 January 